\title{
Chapter 3 \\ Ecosystem Services: The Opportunities of Rewilding in Europe
}

\author{
Yvonne Cerqueira, Laetitia M. Navarro, Joachim Maes, \\ Cristina Marta-Pedroso, João Pradinho Honrado and Henrique M. Pereira
}

\begin{abstract}
Halting the degradation and restoring the full capacity of ecosystems to deliver ecosystem services is currently a major political commitment in Europe. Although still a debated topic, Europe's on-going farmland abandonment is seen as an opportunity to launch a new conservation and economic vision, through the restoration of natural processes via rewilding as a land management option. Despite the ecological interest of restoring a wilder Europe, there is a need to develop evidencebased arguments and explore the broad-range impacts of rewilding. In this chapter
\end{abstract}

\footnotetext{
Y. Cerqueira $(\varangle) \cdot$ L. M. Navarro $\cdot$ H. M. Pereira

Centro de Biologia Ambiental, Faculdade de Ciências da Universidade de Lisboa, Campo

Grande, 1749-016 Lisboa, Portugal

e-mail: yvonnecerqueira@gmail.com
}

\section{Y. Cerqueira $\cdot$ J. Pradinho Honrado}

Centro de Investigação em Biodiversidade e Recursos Genéticos (CIBIO), Departamento de Biologia, Faculdade de Ciências da Universidade do Porto, 4169-007 Porto, Portugal

J. Pradinho Honrado

e-mail: joao.honrado@cibio.up.pt

L. M. Navarro · H. M. Pereira

German Centre for Integrative Biodiversity Research (iDiv) Halle-Jena-Leipzig, Deutscher Platz 5e, 04103 Leipzig, Germany

Institute of Biology, Martin Luther University Halle-Wittenberg, Am Kirchtor 1, 06108 Halle (Saale), Germany

\section{M. Navarro}

e-mail: laetitia.navarro@idiv.de

H. M. Pereira

e-mail: hpereira@idiv.de

\section{J. Maes}

European Commission, Joint Research Centre, Sustainability Assessment Unit, Via Fermi 2749, 21027 Ispra, VA, Italy

e-mail: joachim.maes@jrc.ec.europa.eu

C. Marta-Pedroso

IN+, Center for Innovation, Technology and Policy Research, Environment and Energy Scientific

Area, Instituto Superior Técnico, 1049-001 Lisboa, Portugal

e-mail: cristina.marta@ist.utl.pt 
we study the spatial patterns of ecosystem services in the EU25 and their relationship with wilderness areas. Next we perform a quantitative analysis, at the scale of the Iberian Peninsula, of the supply of ecosystem services in the top 5\% wilderness areas, on agricultural land, and on land projected to be abandoned. We find that high quality wilderness is often associated to high supply of ecosystem services, mainly regulating and cultural. Assuming that high quality wilderness is a good proxy for the future of areas undergoing rewilding, our results suggest that rewilding efforts throughout Europe will enhance the capacity of ecosystems to supply regulating and cultural ecosystem services, such as carbon sequestration and recreation.

Keywords Ecosystem services - Wilderness - Benefits · Farmland abandonment • Human well-being $\cdot$ Rewilding

\subsection{Introduction}

Ecosystem services have been defined as the benefits humans derive from nature through a set of ecosystem functions. The Millennium Ecosystem Assessment (MA 2005) was the stepping-stone in providing a conceptual framework for ecosystem services, which allows for assessing the consequences of ecosystem change for human well-being. Since its publication, multiple classification schemes for ecosystem services have been proposed, such as the framework of The Economics of Ecosystem Biodiversity (TEEB 2012) and, more recently, the Common International Classification of Ecosystem Services or CICES (Haines-Young and Potschin 2012). The CICES was adopted by the European Commission for the Mapping and Assessment of Ecosystem Services initiative (Maes et al. 2013). The CICES categorizes ecosystem services into 3 groups: provisioning (e.g. food, fiber, fuel and water), regulating and maintenance (e.g. air quality, water and soil regulation, natural hazard regulation, climate regulation and disease control) and cultural (e.g. recreation and spiritual).

Although society can easily perceive provisioning ecosystem services such as crops, fish and freshwater, which are all direct benefits to humans, others, such as pollination, erosion control and climate regulation are less tangible. However, directly or indirectly, all ecosystem services underpin environmental and human well-being, economy, and businesses (MA 2005). Many services are not traded in the conventional markets and hence, their economic values remain invisible, tending to be undervalued and consequently overexploited (de Groot et al. 2012). Yet, once lost, replacement can be costly. Wetlands, for example, provide numerous regulating services (e.g. water purification and flood/storm protection), which are unnoticed, in contrast to provisioning services (e.g. timber and food), but highly valuable since degradation can lead to high replacement costs (Reed et al. 2013).

Throughout the world, ecosystem services have been used as a tool in conservation and development as well as poverty alleviation (Tallis et al. 2008). The awareness that ecosystem services affect human well-being and economic 
development has resulted in their integration in the most recent EU Biodiversity Strategy (European Commission 2011a). This strategy aims at halting both biodiversity loss and the degradation of ecosystem services. It also includes the protection of wilderness, specifically old growth forest. Today, $45 \%$ of Europe's land cover is forest ( 1 billion ha) but only $4 \%$ is undisturbed forest ( 6 million ha). Protecting these ecosystems is important as they support particular ecosystem services, such as recreation and air quality (Maes et al. 2012a). Increasing the cover of wilderness areas in Europe trough rewilding of abandoned lands could improve the supply of these services (see Chap. 1). For instance, a recent initiative, "Rewilding Europe" aims at rewilding 1 million ha of land by 2020 (see Chap. 9). However, we have yet to determine what bundle of ecosystem services will rewilded areas provide.

In this chapter, we first investigate the supply and spatial distribution of ecosystem services on a pan-European scale. We then focus on the patterns of spatial overlap between the ecosystem services and wilderness areas. Next, we perform a quantitative analysis of the supply of services in the Iberian Peninsula, comparing the average supply between cultivated areas, high quality wilderness areas and areas currently cultivated but projected to be abandoned. Throughout the analysis, we consider the supply of ecosystem services in wilderness areas as a proxy for the future supply of services in rewilding areas. Finally, we discuss the various economic and ecological benefits of rewilding in Europe.

\subsection{The Spatial Distribution of Ecosystem Services in Europe}

Ecosystems provide a number of essential services underpinning all human life and activities. It is therefore important to recognize the multiple functions from ecosystems and integrate them in management strategies. To manage for multiple ecosystem services we need to map and identify the spatial synergies and trade-offs between services (Maes et al. 2012a; Raudsepp-Hearne et al. 2010). In doing so, we are able to identify ecosystems supporting high level of services and biodiversity (Chan et al. 2006). Along the years, the number of studies mapping ecosystem services has grown, informing both planners and decision makers on how to prioritize the protection and management of ecosystems (Chan et al. 2006; Naidoo and Ricketts 2006).

In the EU Biodiversity Strategy for 2020, the need for spatial assessment of ecosystem services has been included as one of the key actions. Under Action 5, all EU Member States are required to map and assess the state of ecosystems and their services by 2014. The results of this action will also contribute to the assessment of the economic value of ecosystem services, which is to be integrated into the accounting and reporting systems at both EU and national level by 2020 (European Commission 2011b). 
Table 3.1 List of the ecosystem services and corresponding indicators used in the study. (Adapted from Maes et al. 2011). HANPP data were obtained from Haberl et al. (2007)

\begin{tabular}{|c|c|c|c|}
\hline Service & Indicator & Unit & Description/benefit \\
\hline $\begin{array}{l}\text { Food } \\
\text { provision }\end{array}$ & HANPP & $\mathrm{gC} / \mathrm{m}^{2} /$ year & $\begin{array}{l}\text { Human appropriation of net primary } \\
\text { production (cropland and grassland } \\
\text { in this study) }\end{array}$ \\
\hline $\begin{array}{l}\text { Timber } \\
\text { provision }\end{array}$ & Total stock of timber & $\mathrm{m}^{3} / \mathrm{ha}$ & $\begin{array}{l}\text { Production for fuel, construction and } \\
\text { paper. Forest connectivity }\end{array}$ \\
\hline $\begin{array}{l}\text { Freshwater } \\
\text { provision }\end{array}$ & Surface water flow (QFS) & $\mathrm{mm}$ & Renewable freshwater provision \\
\hline \multirow[t]{2}{*}{$\begin{array}{l}\text { Climate } \\
\text { regulation }\end{array}$} & Carbon stock & ton/ha & $\begin{array}{l}\text { Above- and below-ground carbon } \\
\text { stored in living plant material }\end{array}$ \\
\hline & $\begin{array}{l}\text { Net Ecosystem Productivity } \\
\text { (NEP) }\end{array}$ & $\mathrm{mg} / \mathrm{m}^{2} /$ year & Carbon sequestration \\
\hline \multirow[t]{2}{*}{$\begin{array}{l}\text { Water } \\
\text { regulation }\end{array}$} & Nitrogen retention & $\%$ & $\begin{array}{l}\text { Capacity of ecosystems to retain and } \\
\text { process excess nitrogen }\end{array}$ \\
\hline & Soil infiltration capacity & $\mathrm{mm}$ & $\begin{array}{l}\text { Annual summed infiltration capacity } \\
\text { of water }\end{array}$ \\
\hline Air quality & Deposition velocity of Nox & $\mathrm{cm} / \mathrm{s}$ & $\begin{array}{l}\text { Capacity of ecosystems to capture } \\
\text { and remove air pollutants }\end{array}$ \\
\hline Recreation & $\begin{array}{l}\text { Recreation potential index } \\
\text { (RPI) }\end{array}$ & N/A & $\begin{array}{l}\text { Capacity of ecosystems to provide } \\
\text { recreational services }\end{array}$ \\
\hline
\end{tabular}

Here we build on on-going work to map ecosystem services across Europe (Maes et al. 2011). We consider a total of 7 ecosystem services, represented by 9 indicators (Table 3.1). In order for each ecosystem service to contribute equally to the analysis, and following the method of Petter et al. (2013), we standardized the data by reclassifying each service into a quantile split, producing a range of scores from 1 to 5 (five meaning high supply of a specific service). We then summed the 9 indicators to produce a map of "total" ecosystem services supply across Europe (Fig. 3.1a). We used the HANPP (Human Appropriation of Net Primary Production) data presented in Haberl et al. (2007), as the indicator for food provision. The HANPP values were only extracted within agricultural land as to not repeat the information on the provision of timber.

Low stocks for ecosystem service supply appear mainly around urbanized and densely populated areas and in arable land, e.g in central and eastern Spain, southern Romania, eastern UK, and Denmark (Fig. $3.1 \mathrm{a}$ and b). However, low total supply of services does not mean a low quality of the supply of individual services. For example, even if food production were at their highest level in some areas, if that is the only service provided, such area would appear in the low range of the map. High total ecosystem service supply includes mainly pastures, forests and (semi) natural areas, such as the northwest Iberia, Scandinavia, central France, and central Romania. Areas of high total ecosystem service supply in Europe also coincide with mountain regions (Fig. 3.1a), mainly consisting of forest and (semi)-natural areas (Fig. 3.1b). 


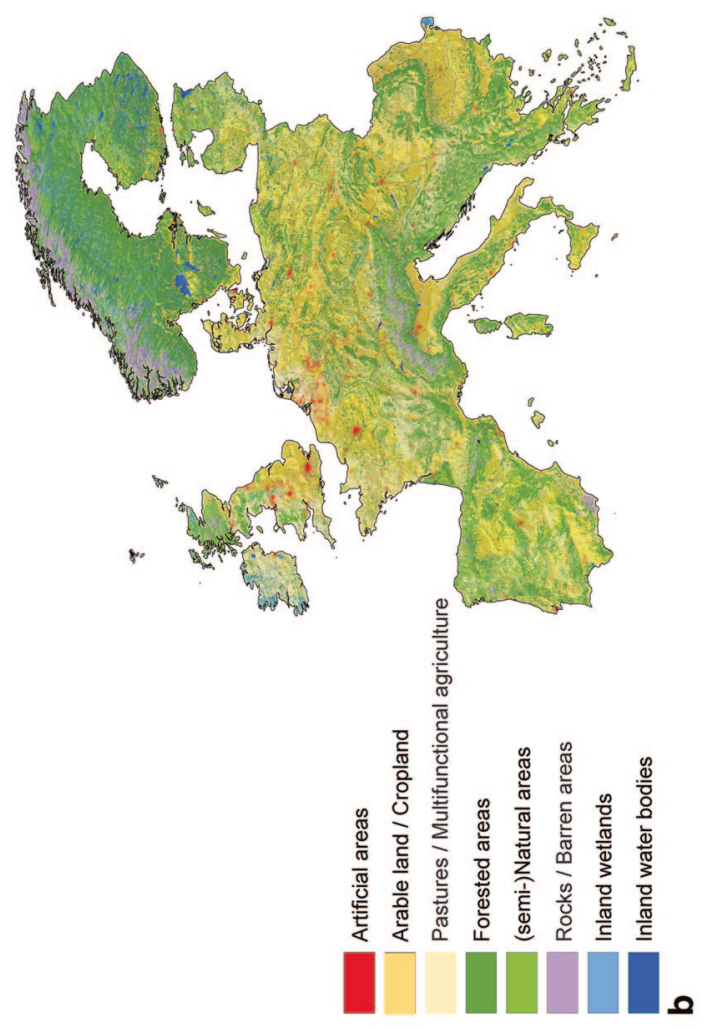

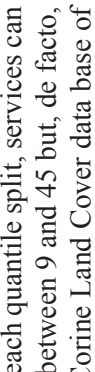

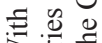

3

$\dot{m} \triangleq 0$

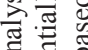

ते छ

$\because \frac{0}{0}$

至苛

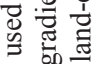

늘

西

ले

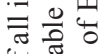

늉 ิㅡㄹ

兽芯

क

氜

宁.

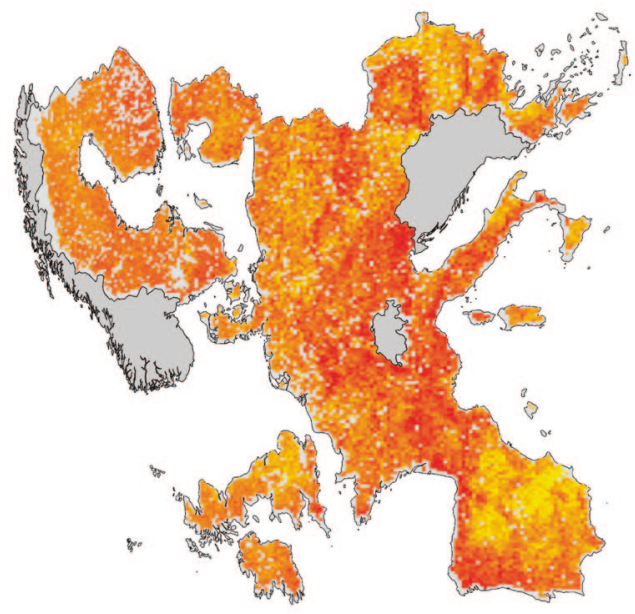

设

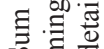

की है

등

合命焉.

氜施

$\exists \stackrel{\infty}{\infty} \geq$

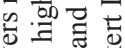

o 9 는

i⿱

ज $:$ ज

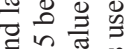

的管

ठ․ㅋ छ

可声

啨品

हैं हैं

ฟิ

0 政

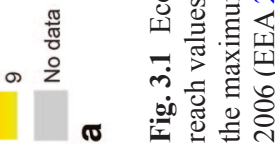


Changes in human demand for services associated with specific land uses have shown diverging trends in Europe, varying between regions. In general the supply of crops, timber (mainly in northern countries), freshwater, and recreation has increased in the last 50 years while livestock production and wild foods supply have followed a decreasing trend throughout much of Europe's rural areas (Harrison et al. 2010). Other studies suggest that unsustainable farming practices and mismanagement through agricultural intensification have contributed to the loss of habitat and biodiversity, soil erosion and nutrient runoff (Dunbar et al. 2013).

\subsection{Wilderness, Rewilding and Ecosystem Services}

\section{Wilderness}

Wilderness areas have been defined as large natural areas, unmodified or slightly modified, governed by natural processes, with no human intervention, infrastructure or permanent habitation present (Wild Europe 2012). Nordic mountains represent the highest proportion (28\%) of wildest areas, followed by the Pyrenees (12\%) the eastern Mediterranean islands and Alps (9\%), and British Isles (8\%) (Carver 2010). However, remnants can also be found throughout much of the continent, where anthropogenic interference has slightly altered the natural ecological conditions (Carver 2010). The definition of wilderness will depend on the metrics chosen (see Chap. 2) and, as a result, its spatial distribution can vary from one study to another. Currently, there are several maps on potential wilderness in Europe. Here we chose to use Carver's (2010) quality wilderness index.

Wild ecosystems provide a wide range of ecosystem services. They are stable and self-sustainable, able to maintain their structure, function and resilience over time (Costanza and Mageau 1999). They play an important role in protecting services such as, air quality, freshwater provision, and supporting wildlife, including charismatic species, such as bisons and bears, that are reliant on wilderness areas (Russo 2006; see Chap. 9). Wild ecosystems also have the capacity to supply higher quality services than other types of systems. For example, there is higher carbon storage capacity in undisturbed forest, peatland and wetland (Schils et al. 2008), subsequently providing additional environmental benefits (e.g. biodiversity, water storage and water quality). Moreover, wilderness areas provide a range of social and economic benefits. Several programs have integrated the use of wild areas to address urban issues such as youth at risk, youth development and rehabilitation (Hill 2007), and recognized it as a cost-effective form of healthcare. In addition, wilderness inspires educational programs (e.g. Chap. 10). Wilderness areas also provide spiritual benefits, such as, solitude, places of inspiration, a calm environment, and recreation/tourism (Ewert et al. 2011; Heintzman 2013). These cultural services can give birth to employment opportunities and thus generate income. For example, the Oulanka National Park in Finland brings 14 million $€$ per year to the local economy and employs 183 individuals (Huhtala et al. 2010). 


\section{Methods}

We used Carver's (2010) wilderness quality map and the same quantile approach described earlier in Sect. 3.2, to produce a gradient of wilderness quality with qualitative values ranging between 1 and 4 (4 meaning the highest wilderness quantile and high supply of ecosystem services). We then grouped the ecosystem services into provisioning, regulating, and cultural services and followed the same splitting approach for each group of services. The ecosystem services maps were then overlaid with the wilderness map. To determine the relationship between gradients of both ecosystem services supply and wilderness quality, we display the overlay of high and low wilderness with high and low supply of ecosystem services (Fig. 3.2a, b, c and d). Furthermore, we used the projections of the CLUE model (Verburg and Overmars 2009) to assess the potential change in the provision of ecosystem services with scenarios of land abandonment and rewilding in Europe for 2030. We considered as potential land abandonment and rewilding the cells classified as arable land, pasture, irrigated arable land, permanent crops in 2000 and classified in 2030 in all four EURURALIS scenarios as (semi)-natural vegetation, forest, recently abandoned arable land and recently abandoned pasture land. For quantitative comparisons, we calculated the mean provision of ecosystem service (per $\mathrm{km}^{2}$ ) in agricultural areas (based on the 2000 land use map, in Verburg and Overmars 2009 ), in the top $5 \%$ high quality wilderness, and in the areas currently under agricultural use but projected to become abandoned by 2030, in the Iberian Peninsula (Table 3.2). Differences between the distributions of the mean ecosystem service values for each type of land-use were assessed using a Kruskal-Wallis test. Finally, we calculated the ratio between the average supply of each indicator in either the top $5 \%$ wilderness areas and in agricultural areas relative to the areas projected to be abandoned. All mapping and data extraction were done using ArcGIS version 10.3, while the statistical analysis was done using $\mathrm{R}$ version 2.15.3.

\section{Wilderness and Ecosystem Services}

Some high wilderness areas are associated to regions supplying high ecosystem services, particularly in mountain regions (Fig. 3.2a). As expected, the overlay of provisioning services and wilderness (Fig. 3.2b) exhibits relatively large areas of high supply of services and low wilderness (e.g. in France, Benelux and Germany), along with areas of low service supply and high wilderness (e.g. Northern Scandinavia). This is not surprising since wilderness areas are typically associated with low to no extraction of natural resources. There are nonetheless high provisioning services in some areas of high wilderness quality, mainly associated to mountain regions (e.g. some areas of the Alps and Apennines). This can be due to the occurrence of large quantities of resources for some provisioning services (i.e. timber and freshwater) in mountain regions, which still happen to be wilder than the rest of Europe. 
All services

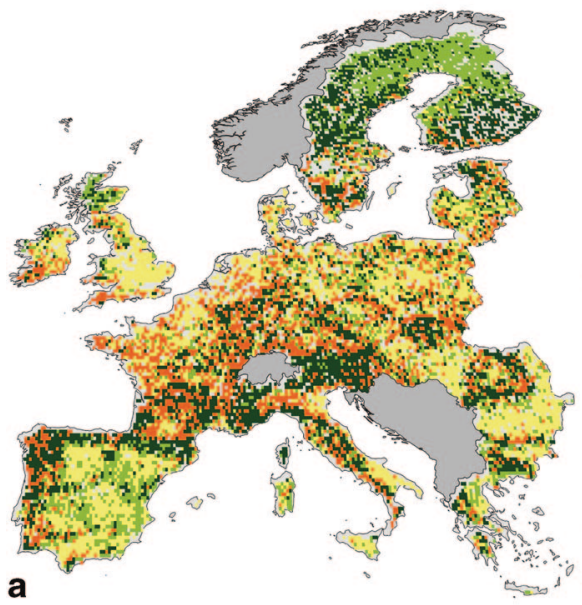

Regulating services
Provisioning services

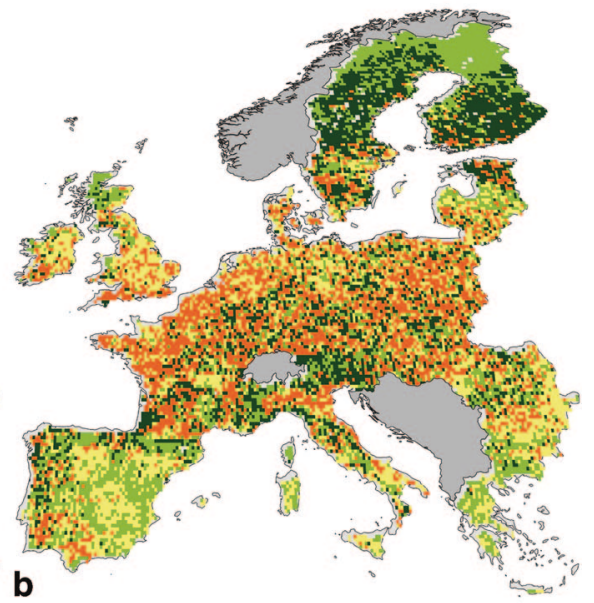

Recreational (cultural) services
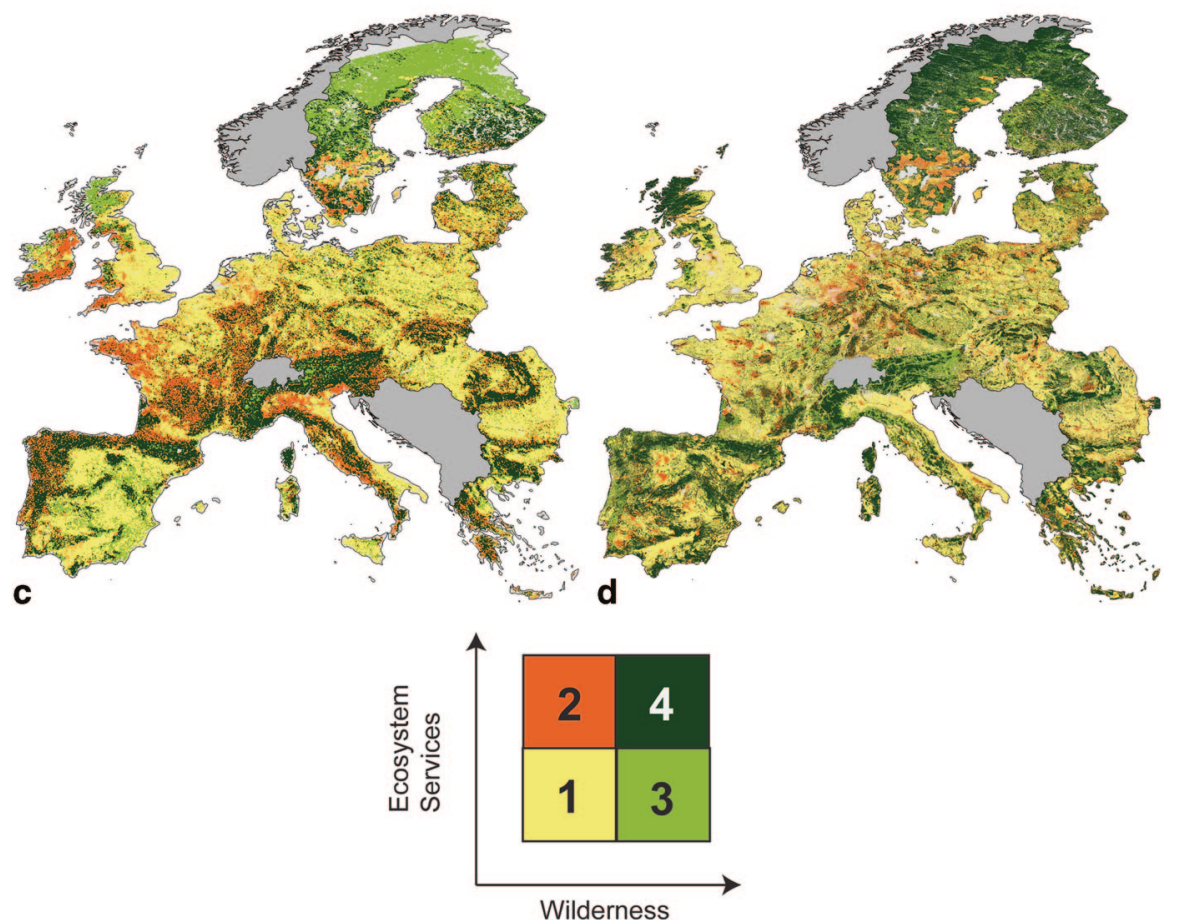

Fig. 3.2 Ecosystem services and wilderness in Europe. For each map, the quantile splits of ecosystem services and wilderness were overlaid to present a gradient of both wilderness and service supply. For an easier representation, the values were grouped into "low" (bottom 50\%) and "high" (top 50\%) for both metrics and then grouped, e.g. low supply of services and low wilderness (see color key on the figure). a All indicators for all services versus wilderness; $\mathbf{b}$ Indicators of provisioning services versus wilderness; c Indicators of regulating services versus wilderness; and $\mathbf{d}$ Recreational service versus wilderness. (See Table 3.1 for details on the indicators used). (Sources: Carver 2010; Maes et al. 2011) 


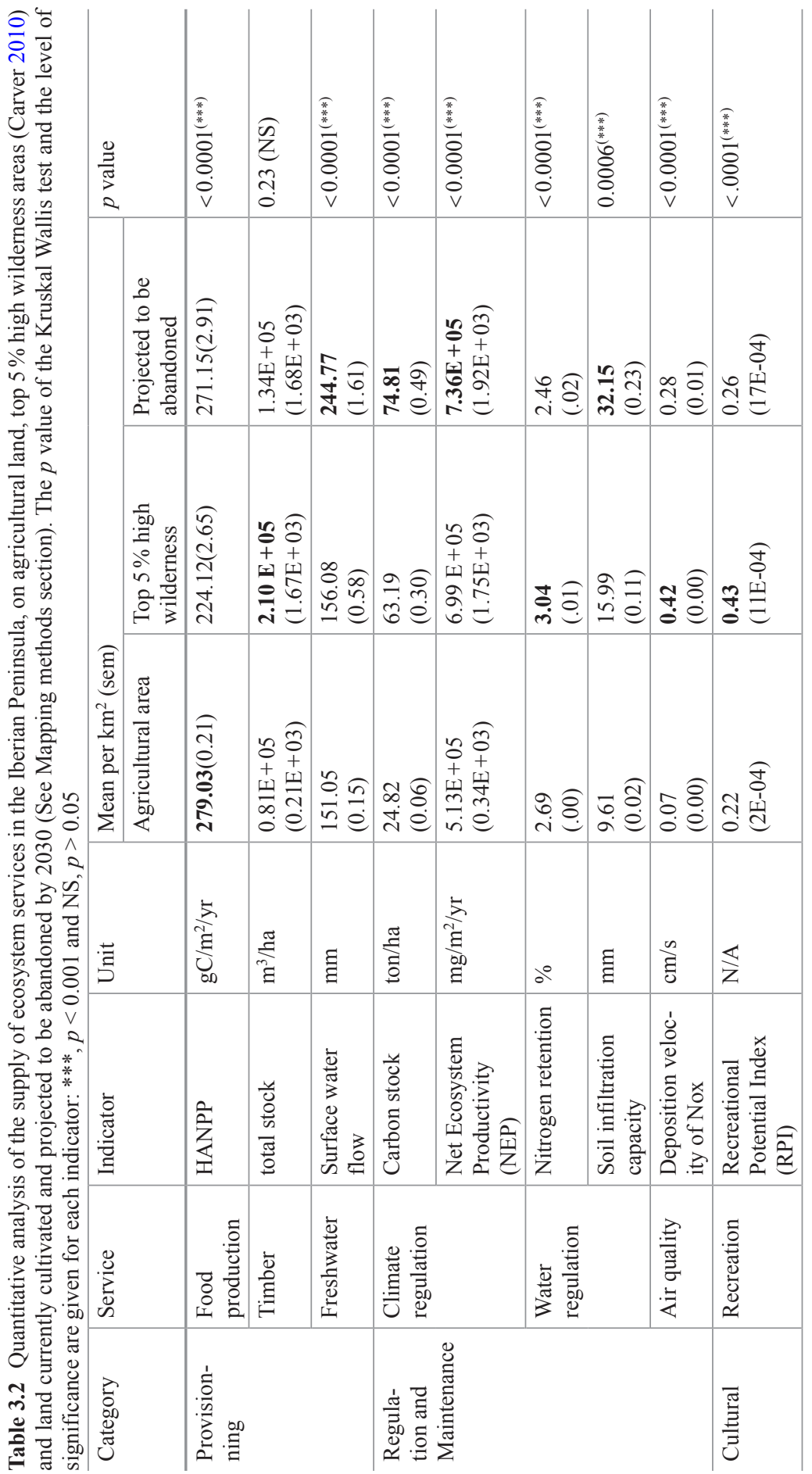


The spatial distribution of wilderness coincides more with regulating services than with provisioning services (Fig. 3.2c). Areas of Europe containing both high supply of services and high degrees of wilderness include mountainous areas in Northern Iberia, Austria, and Italy. Most of the continent is still represented by areas of both low regulating services and low wilderness (e.g. Eastern UK, Poland), which also coincides with agricultural areas (Fig. 3.1b). Interestingly, several areas of high supply of regulating services and low wilderness also exist (Western France and Ireland).

Finally, for recreational services (Fig. 3.2d), we found a predominance of either areas of low service supply and low wilderness, or areas of high wilderness and high service supply, suggesting this is the category of services most strongly associated with wilderness. However there are some areas of low wilderness and high service supply or areas with high wilderness but low recreation potential. Typically, the flow of recreational services is calculated as the product between the capacity of an area to supply recreational services and the accessibility of this area (Maes et al. 2011). As a result, it can occur that an ecosystem would be of extreme beauty or wilderness quality but not accessible, leading to a low flow of recreation and other cultural services, or that an area would be less natural but still be an important cultural landscape that is easily accessible.

Taken as a whole, regulating and cultural services are often associated to high wilderness areas (Fig. 3.2b and c), particularly mountain systems. Mountain ecosystems cover approximately $41 \%$ of Europe's territory, providing various services due to their multifunctionality. Mountains are "water towers" as they provide water for multiple uses, including irrigation, human consumption, and hydropower (Viviroli et al. 2007). Mountain systems supply cultural services, holding spiritual value to local inhabitants, and are recreation and ecotourism attractions (Price et al. 1997). In mountain systems there is a high proportion of habitat types with favorable conservation status (EEA 2010b), playing a key role in supplying many ecosystem services and maintaining ecological processes (Harrison et al. 2010). Forests make up $41 \%$ of mountain systems (Körner et al. 2005) and can be regulators of natural disasters as the soils of mature forests have high infiltration rate, thus reducing peak flows and floods (Maes et al. 2009). Forests also provide a range of services such as carbon sequestration, air quality regulation, timber for fuelwood and non-timber products (game and medicinal plants), and climate regulation (Harrison et al. 2010; Maes et al. 2012b). Peatlands store large quantities of carbon and have played a fundamental role in climate regulation and are critical for water regulation. Grasslands are the habitat of a large number of species, such as wild pollinators (Kremen et al. 2002), which makes them essential in underpinning biodiversity and ecosystem services. Finally, mountains are also hotspots of endemism. In Europe, the highest number of endemic species can be found in the Alps and the Pyrenees (Väre et al. 2003). 


\section{Ecosystem Services and Scenarios of Rewilding}

Here we estimate the biophysical potential of rewilding to produce benefits, by comparing ecosystem services in the top 5\% wilderness areas with the current supply of ecosystem services in all agricultural areas and in agricultural areas that are projected to be abandoned. We restrict the analysis to the scale of the Iberian Peninsula to control for the large bioclimatic variability across Europe.

There are significant differences in the supply of most ecosystem services between the different land use categories (Table 3.2). HANPP values are significantly higher in agricultural areas than in both land projected to be abandoned and, as expected, in the top $5 \%$ wilderness areas. We thus hypothesize that food production will decrease with the contraction of the agricultural area, although the decrease will be limited because of the lower agricultural productivity of those areas. Several services present higher values for the average supply of the studied indicators in the top $5 \%$ wilderness areas (Table 3.2). The deposition velocity of NOx, an indicator of air quality, depends on the height of the vegetation and the leaf area index, and tends to be much higher in forested areas (Maes et al. 2011), hence, the higher values in the top $5 \%$ wilderness (Table 3.2). The recreation potential is also higher in wilderness areas than in the other land-uses.

Most ecosystem services exhibit higher values in the areas to be abandoned than in other agricultural areas (Fig. 3.3a). We can thus speculate that intensifying agriculture in the areas projected to be abandoned would lead to an overall decrease in the supply of ecosystem services in these areas. On the other hand, rewilding these areas would bring improvements in some ecosystem services, such as nitrogen retention and recreation, and decreases in others (Fig. 3.3b). These inferences have to be interpreted with care as we are making several simplifying assumptions and ecosystem services depend on other biophysical variables besides land cover and

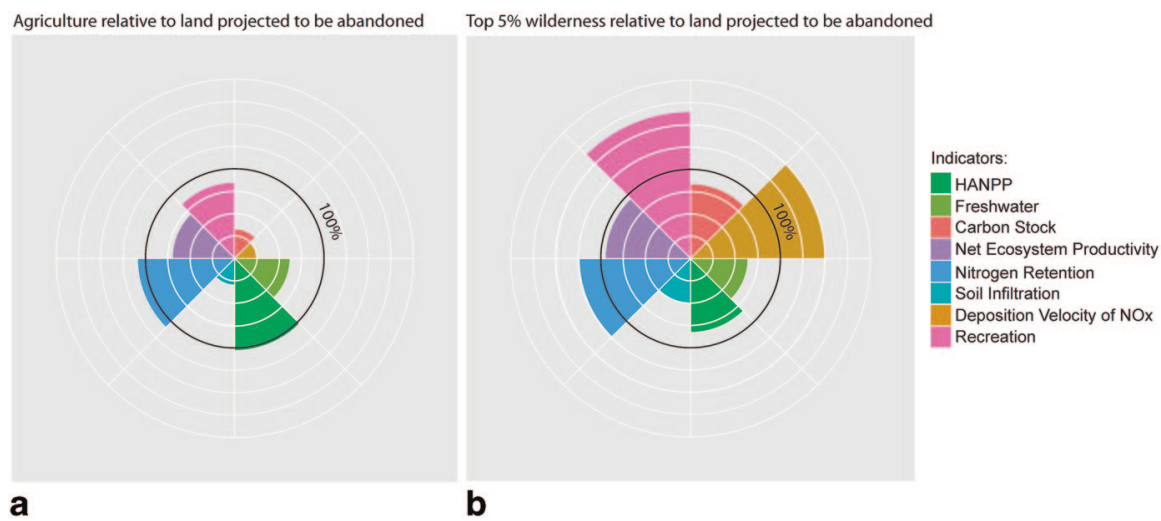

Fig. 3.3 Comparison between land-uses of the average supply of indicators of ecosystem services. The diagrams represent the average supply per $\mathrm{km}^{2}$ in cultivated areas (a), or in the top $5 \%$ wilderness (b), relative to the average supply in areas projected to be abandoned. Values inside the $100 \%$ circle are lower for the studied land-use, while values outside are higher when compared with land projected to be abandoned. See Table 3.2 for the average values. 
land use. This is for instance the case for freshwater supply, which depends on the aboveground net precipitation water in catchments and on the area and flows of the freshwater areas (Maes et al. 2011).

\subsection{The Economic Benefits of Rewilding}

In the previous sections we used models of the spatial distribution of ecosystem services to look at the potential impacts of rewilding on biophysical metrics of indicator supply. We now review case studies of economic valuation of ecosystems services provided by natural habitats and by ecological restoration.

\section{Regulating Benefits}

In Lowland England, studies on different land use management options have shown that the cost and benefits of changes in ecosystem services from rewilding outweigh those from arable and dairy farming (NERC 2012). In the Upland UK estimates show that managing the land for carbon storage and sequestration through the restoration of peatlands may be more profitable than pastoral activities (Reed et al. 2013). Peatlands, in Scotland, have been valued between 49 million $€$ and $196 €$ per annum for carbon sequestration (McMorran et al. 2006).

Forest regeneration will also provide major increases in carbon sequestration. It has been estimated that within the Natura 2000 network, commercial and wild forest habitats generate the highest carbon value estimated at $318.3 €$ and 610.1 billion $€$, in 2010 followed by grassland systems ranging between $105.6 €$ and 196.5 billion $€$ (ten Brink et al. 2011). In the Carpathians, the protection of old growth forest is expected to generate 26 million $€$ through carbon offsets (ten Brink et al. 2011). In the Hoge Veluwe Forest, a protected area of the Netherlands, total economic benefit generated by forests is $2000 €$ ha/year, for the following services: wood production, supply of game, groundwater recharge, carbon sequestration, air filtration, recreation and nature conservation. This value is calculated to be three times higher than adjacent agricultural land (Hein 2011).

Although there is still a lack of available information on the economic value of water purification at the EU level, studies suggest that cities such as Berlin, Vienna, Oslo, and Munich benefit from the natural treatment from ecosystems in protected and non protected areas, with annual economic benefits ranging between $7 €$ and 16 million $€$ for water purification and $12 €$ and 91 million $€$ for water provision per city (ten Brink et al. 2011). In the archipelago of the Azores, the restoration of pastures to native forests would result in an economic benefit of $110 €$ thousand per year from water purification (Cruz and Benedicto 2009). These examples, though limited, demonstrate that protecting and restoring natural vegetation is of economic benefit, and could contribute to achieve the goals of the Water Framework Directive. 
Floodplains (wetlands) are also important ecosystems for water cycle regulation, acting as natural sponges, they retain water in river basins, slowly releasing the water down river and into groundwater. Moreover, they play a fundamental role in filtering out pollutants and are home to much wildlife. Restoring the function of floodplains in EU countries could save approximately 1.4 billion $€$ of treatment costs for water purification and reduce annual cost of flood damage, currently at 6.4 billion $€$ and expected to increase (Feyen and Watkiss 2011). Of course, this type of ecosystem restoration has initial costs. The Danube Basin restoration project estimates that the recovery of 100,000 ha, would cost $500,000 € / \mathrm{km}^{2}$, i.e. an investment of 500 million $€$. However, this value is still estimated to be much lower than the costs associated to damage control and the improvement of dykes (WWF 2010).

Degradation of natural ecosystems has also been linked to the intensification of other natural hazards (Dudley et al. 2010). For example, in the Swiss Alps the protection of old forests contribute to disaster prevention (e.g. avalanches and landslides) and have been analyzed at a value of 1.6-2.8 billion $€$ per year (IPCDR 2010). Additionally, the role of European pristine scrublands and Belgian grasslands against soil erosion was valued at $44.5 €$ /ha (Kettunen et al. 2012).

\section{Cultural Benefits}

Economic benefits from non-extractive activities such as nature tourism and recreation boost local and regional economies, providing income and employment to communities and private landholders who face limited alternative livelihoods, especially in a context of rural depopulation of marginal areas (Brown et al. 2011; McMorran et al. 2006). Furthermore, the aims of eco-tourism are closely associated with biodiversity conservation. Through the promotion of rewilding efforts, there will be an increase in the connectivity of landscapes, creating an opportunity for the expansion of large mammals and other species (Russo 2006), and indirectly increasing tourism while generating economic benefits to local communities.

Presently, eco-tourism is the fastest growing component sector in tourism (Gössling 2000). Overall, tourism is the largest global economic sector accounting for $\$ 3.6$ trillion in economic activity and eco-tourism has constantly increased 20-30\% per year since the early 1990's (Bishop et al. 2008). Eco-tourism is defined by the International Ecotourism Society as the responsible visiting to natural areas that conserves the environment and improves the well-being of local people. For instance, in Zarnesti, Romania, a small community increased their total local revenue from $140,000 €$ in 2001 to $260,000 €$ in 2002 through eco-tourism programmes (CLCP 2000).

In particular, wildlife areas appeal to a large spectrum of tourists given the presence of charismatic species and other rare or attractive species. For example the reintroduction of wolves in the Yellowstone National Park has attracted additional tourists, generating economic and social benefits estimated at US\$ 6-9 million per year (Donlan et al. 2006). The reintroduction of ungulates and large carnivores 
in the Majella and the Retezat National Park in Italy and Romania, respectively, has also contributed to the local economy (Kun and van der Donk 2006). In Scotland, tourism from wild landscapes is one of the most important economic sectors, contributing 1.6 billion $€$ annually, to the country's economy. In particular, recreation opportunities, such as wildlife watching and hillwalking, generate 65 million $€$ and support 39,000 full time jobs (Brown et al. 2011; Bryden et al. 2010). The reintroduction of the beaver can potentially generate an additional $£ 2$ million per year into the local Scottish economy through eco-tourism (Campbell et al. 2007). In addition to its potential economic benefits, beaver dams are considered to have a positive impact on river systems by increasing both invertebrate and fish populations (Kemp et al. 2010).

The Natura 2000 network further exemplifies how biodiversity can be protected while generating benefits. Annually, the gross socio-economic and co-benefits (social and environmental) from the Natura 2000 network range between 223 billion $€$ and 314 billion $€$, representing between 2 and $3 \%$ of EU's GDP (ten Brink et al. 2011). This figure contrasts with the annual investment in the Natura 2000 network, estimated at 5.8 billion $€$ while providing 8 million (FTE) jobs (Gantolier et al. 2010).

\subsection{Discussion}

The degradation, or land conversion, of natural ecosystems alters not only species richness and composition; it reduces ecosystem functionality, impacting the flow of ecosystem services, the costs of recuperation and ultimately human well-being (Flynn et al. 2009). Global and EU targets were designed for the conservation and restoration of natural ecosystems, including the biodiversity and ecosystem services that they sustain (see Chap. 11). For instance, Target 2 of the EU 2020 biodiversity strategy promotes the restoration and the use of green infrastructures (i.e interconnected network of ecosystems, such as wetlands and woodlands) with the goal of restoring $15 \%$ of degraded ecosystems, through incentives based on EU funding and Public Private Partnerships (European Commission 2011a). In this context, the restoration of nature through rewilding can be seen as a solution to address the on-going agricultural land abandonment while developing a new rural economy offering multiple social and environmental benefits (Brown et al. 2011; Bryden et al. 2010; Donlan et al. 2006; Gantolier et al. 2010; Hein 2011; McMorran et al. 2006).

We investigated the existence of the spatial co-occurrence of wilderness and ecosystem services supply at the EU scale (Fig. 3.2). Our results further suggest that the opportunity of restoring abandoned land in the Iberian Peninsula to a self-sustained natural state, via rewilding, could increase the supply of regulating and cultural services (Table 3.2 and Fig. 3.3). We thus argue that by restoring and sustaining wilderness areas we are underpinning a supply of high quality ecosystem services provided by those areas. These services will also heighten a new local economy, providing an economic break for the remaining rural communities through the creation of jobs and income generated from incentives, including from payments for ecosystem services, carbon markets, biodiversity markets, and eco-tourism (e.g. 
Bishop et al. 2008; Jack et al. 2008; Pirard 2012; TEEB 2010). Although, the concept of rewilding is fairly recent in Europe, it has already been identified as a costeffective management strategy for traditional land uses in Scotland (Brown et al. 2011; McMorran et al. 2006). In the Netherlands, rewilding has been positively perceived by people: individuals attribute a low willingness to pay for the conservation of extensive farming versus rewilding initiatives (van Berkel and Verburg 2014).

Farmland abandonment can lead to the potential loss of traditional cultural values and heritage, including local knowledge on farming and resource management, and locally adapted animal breeds and crop varieties (Cerqueira et al. 2010). Thus, choices have to be made case by case, and strategies should be designed to mitigate and avoid cultural losses. Furthermore, extensive agriculture and the maintenance of traditional activities provide a different bundle of ecosystem services from rewilding. Therefore, there might be instances where local communities or the public will prefer the bundle of services associated with rewilding, while in other places the bundle of services associated with extensive agriculture will be chosen.

In conclusion, we are not suggesting that rewilding efforts through assisted or passive restoration be the only solution to Europe's present situation. Instead we think it should be considered as a potential strategy in those areas where the socialecological dynamics of the landscape are no longer socially, economically or environmentally sustainable. Yet, there are still many challenges in understanding the full relationship between landscape management, the supply of ecosystem services, and the economic benefits and costs associated to each management type. We believe we need further research on the environmental, social and economic benefits associated to wilderness and rewilded areas. Raising awareness of these benefits may help to promote the concept of rewilding, and help gain momentum to define public policies and funding for rewilding activities.

Acknowledgments We thank Vânia Proença and Alexandra Marques for insightful comments on earlier versions of the manuscript. L.M.N. was supported by a PhD fellowship from the FCT (SFRH/BD/62547/2009).

Open Access This chapter is distributed under the terms of the Creative Commons Attribution Noncommercial License, which permits any noncommercial use, distribution, and reproduction in any medium, provided the original author(s) and source are credited.

\section{References}

Bishop, J., Kapila, S., Hicks, F., Mitchell, P., \& Vorhies, F. (2008). Building biodiversity business (164 pp). London: Shell International Limited and the International Union for Conservation of Nature.

Brown, C., Mcmorran, R., \& Price, M. F. (2011). Rewilding-A new paradigm for nature conservation in Scotland? Scottish Geographical Journal, 127(4), 288-314.

Bryden, D. M., Westbrook, S. R., Burns, B., Taylor, W. A., \& Anderson, S. (2010). Assessing the economic impacts of nature based tourism in Scotland-Commissioned Report No. 398. Scottish Natural Heritage.

Campbell, R. D., Dutton, A., \& Hughes, J. (2007). Economic impacts of the beaver. Report for the Wild Britain Initiative. Oxon, UK, 28 p. 
Carver, S. (2010). Chapter 10.3 Mountains and wilderness. In Europe's ecological backbone: Recognising the true value of our mountains (No. 6/2010). European Environment Agency. Copenhagen, Denmark, 248 pp.

Cerqueira, Y., Araujo, C., Vicente, J., Pereira, H. M., \& Honrado, J. (2010). Ecological and cultural consequences od agricultural abandonment in the Peneda-Gerês National Park (portugal). In N. Evelpiou, et al. (Eds.), Natural Heritage from East to West. (pp. 175-183). Berlin: Springer.

Chan, K., Shaw, M., Cameron, D., Underwood, E., \& Daily, G. (2006). Conservation planning for ecosystem services. PLoS Biology, 4(11), 2138-2152. doi:10.1371/journal.pbio.0040379.

CLCP. (2000). Annual Report. Zarnesti Romania: Carpathian Large Carnivore Project.

Costanza, R., \& Mageau, M. (1999). What is a healthy ecosystem? Aquatic Ecology, 33(1), 105115. doi:10.1023/A:1009930313242.

Cruz, A. de la, \& Benedicto, J. (2009). Assessing Socio-economic Benefits of Natura 2000-A Case Study on the ecosystem service provided by SPA PICO DA VARA/RIBEIRA DO GUILHERME. Output of the project Financing Natura 2000: Cost estimate and benefits of Natura 2000 (Contract No.: 070307/2007/484403/MAR/B2). 43 pp.

De Groot, R., Brander, L., van der Ploeg, S., Costanza, R., Bernard, F., Braat, L., \& van Beukering, P. (2012). Global estimates of the value of ecosystems and their services in monetary units. Ecosystem Services, 1(1), 50-61. doi:10.1016/j.ecoser.2012.07.005.

Donlan, C. J., Berger, J., Bock, C. E., Bock, J. H., Burney, D. A., Estes, J. A., et al. (2006). Pleistocene rewilding: An optimistic agenda for twenty-first century conservation. American Naturalist, 168(5), 660-681.

Dudley, N., Stolton, S., Belokurov, A., Krueger, L., Lopoukhine, N., MacKinnon, K., Sandwith, T., \& Sekhran N. (Eds.). (2010). Natural solutions: Protected areas helping people cope with climate change. Gland: IUCN, WCPA, TNC, UNDP, WCS, The World Bank and WWF.

Dunbar, M. B., Panagos, P., \& Montanarella, L. (2013). European perspective of ecosystem services and related policies. Integrated Environmental Assessment and Management, 9(2), 231-236.

EEA. (2010a). Corine Land Cover 2006 raster data. European Environment Agency.

EEA. (2010b). Integrated assessment of Europe's mountain areas. Copenhagen: European Environment Agency.

European Commission. (2011a). Our life insurance, our natural capital: An EU biodiversity strategy to 2020 (No. COM (2011) 244 final). Brussels: European Comission.

European Commission. (2011b). The EU Biodiversity Strategy to 2020. Luxembourg, 27pp,

Ewert, A., Overholt, J., Alison, V., \& Wang, C. (2011). Understanding the Transformative Aspects of the Wilderness and Protected Lands Experience upon Human Health. USDA Forest Service Proceedings RMRS-P-64: P. 140-146.

Feyen, L., \& Watkiss, P. (2011). Technical policy briefing note 3: The impacts and economic costs of river floods in Europe, and the costs and benefits of adaptation. Sweden: Stockholm Environment Institute.

Flynn, D. F., Gogol-Prokurat, M., Nogeire, T., Molinari, N., Richers, B. T., Lin, B. B., \& DeClerck, F. (2009). Loss of functional diversity under land use intensification across multiple taxa. Ecology Letters, 12(1), 22-33.

Gantolier, S., Rayment, M., Bassi, S., Kettunen, M., McConville, A., Landgrebe, R., \& ten Brink, P. (2010). Costs and socio-economic benefits associated with the natura 2000 network. Final report to the European commission. (No. G Environment on Contract ENV.B.2/SER/2008/0038.) (p. 181). Brussels: Institute for European Environmental Policy/GHK/Ecologic.

Gössling, S. (2000). Tourism—sustainable development option? Environmental Conservation, 27(03), 223-224.

Haberl, H., Erb, K. H., Krausmann, F., Gaube, V., Bondeau, A., Plutzar, C., \& Fischer-Kowalski, M. (2007). Quantifying and mapping the human appropriation of net primary production in earth's terrestrial ecosystems. Proceedings of the National Academy of Sciences, 104(31), 12942-12947.

Haines-Young, R., \& Potschin, M. (2012). CICES V4.3-Report prepared following consultation on CICES Version 4. EA Framework Contract No EEA/IEA/09/003. 
Harrison, P. A., Vandewalle, M., Sykes, M. T., Berry, P. M., Bugter, R., de Bello, F., \& Haslett, J. R. (2010). Identifying and prioritising services in European terrestrial and freshwater ecosystems. Biodiversity and Conservation, 19(10), 2791-2821.

Hein, L. (2011). Economic benefits generated by protected areas: The case of the Hoge Veluwe forest, the Netherlands. Ecology \& Society, 16(2), 13.

Heintzman, P. (2013). Spiritual outcomes of park experience: A synthesis of recent social science research. George Wright Forum, 30, 273-279.

Hill, N. R. (2007). Wilderness therapy as a treatment modality for at-risk youth: A primer for mental health counselors. Journal of Mental Health Counseling, 29(4), 338-349.

Huhtala, M., Kajala, L., \& Vatanen, E. (2010). Local economic impacts of national park visitors' spending in Finland: The development process of an estimation method. Working papers of the Finnish forest research institute 149. http://www.researchgate.net/publication/228455705 Local_economic_impacts_of_national_park_visitors'spending_in_Finland_The_development_process_of_an_estimation_method/file/50463528343f6c63cc.pdf.

IPCDR. (2010). Promoting Payments for Ecosystem Services in the Danube Basin. Danube Watch-the Magazine of the Danube River, 3.

Jack, B. K., Kousky, C., \& Sims, K. R. E. (2008). Designing payments for ecosystem services: Lessons from previous experience with incentive-based mechanisms. Proceedings of the $\mathrm{Na}$ tional Academy of Sciences, 105(28), 9465-9470. doi:10.1073/pnas.0705503104.

Kemp, P. S., Worthington, T. A., \& Langford, T. E. L. (2010). A critical review of the effects of beavers upon fish and fish stocks. Scottish Natural Heritage Commissioned Report No. 349 (iBids No. 8770).

Kettunen, M., Vihervaara, P., Kinnunen, S., D’Amato, D., Badura, T., Argimon, M., \& ten Brink, P. (2012). Socio-economic importance of ecosystem services in the Nordic Countries. The Economics of Ecosystems and Biodiversity (TEEB).

Körner, C., Spehn, E., \& Baron, J. (2005). Mountain systems. In W. R. Institute (Ed.), Millennium ecosystem assessment: Ecosystems and human well-being: Synthesis. Island Press, Washington DC.

Kremen, C., Williams, N. M., \& Thorp, R. W. (2002). Crop pollination from native bees at risk from agricultural intensification. Proceedings of the National Academy of Sciences, 99(26), 16812-16816.

Kun, Z., \& van der Donk, M. (2006). Providing wilderness experience opportunities in Europe's certified PAN parks. Parks, 16(2), 34-40.

MA. (2005). Millennium ecosystem assessment: Ecosystems and human well-being: Synthesis. Washington, D.C.: Island Press.

Maes, W. H., Heuvelmans, G., \& Muys, B. (2009). Assessment of land use impact on water-related ecosystem services capturing the integrated terrestrial- aquatic system. Environmental Science \& Technology, 43(19), 7324-7330.

Maes, J., Paracchini, M. L., \& Zulian, G. (2011). A European assessment of the provision of ecosystem services: Towards an Atlas of ecosystem services. Luxembourg: European Union.

Maes, J., Paracchini, M. L., Zulian, G., Dunbar, M. B., \& Alkemade, R. (2012a). Synergies and trade-offs between ecosystem service supply, biodiversity, and habitat conservation status in Europe. Biological Conservation, 155, 1-12.

Maes, J., Hauck, J., Paracchini, M. L., Ratamäki, O., Termansen, M., Perez-Soba, M., et al. (2012b). A spatial assessment of ecosystem services in Europe: Methods, case studies and policy analysis-phase 2 Synthesis report (PEER Report No. 4).

Maes, J., Teller, A., Erhard, M., Liquete, C., Braat, L., Berry, P., \& Bidoglio, G. (2013). Mapping and assessment of ecosystems and their services. An analytical framework for ecosystem assessments under action 5 of the EU biodiversity strategy to 2020. Luxembourg: European Comissions.

McMorran, R., Price, M. F., \& McVittie, A. (2006). A review of the benefits and opportunities attributed to Scotland's landscapes of wild character. Scottish Natural Heritage Commissioned Report No. 194 (ROAME No. F04NC18).

Naidoo, R., \& Ricketts, T. H. (2006). Mapping the economic costs and benefits of conservation. PLoS Biology, 4(11), e360. 
NERC. (2012). Valuing ecosystem services: Case studies from lowland England. Annex 4- Knepp Castle Estate Re-wilding:Sussex. Natural England.

Petter, M., Mooney, S., Maynard, S. M., Davidson, A., Cox, M., \& Horosak, I. (2013). A Methodology to map ecosystem functions to support ecosystem services assessments. Ecology \& Society, 18(1), 31.

Pirard, R. (2012). Market-based instruments for biodiversity and ecosystem services: A lexicon. Environmental Science \& Policy, 19-20, 59-68. doi:10.1016/j.envsci.2012.02.001.

Price, M. F., Moss, L. A., \& Williams, P. W. (1997). Tourism and amenity migration. In B. Messerli \& J. D. Ives (Eds.), Mountains of the world: A global priority (pp. 249-280). Parthenon Publishing Group, New York.

Raudsepp-Hearne, C., Peterson, G. D., \& Bennett, E. M. (2010). Ecosystem service bundles for analyzing tradeoffs in diverse landscapes. Proceedings of the National Academy of Sciences, 107(11), 5242-5247. doi:10.1073/pnas.0907284107.

Reed, M. S., Hubacek, K., Bonn, A., Burt, T. P., Holden, J., Stringer, L. C., et al. (2013). Anticipating and managing future trade-offs and complementarities between ecosystem services. Ecology and Society, 18(1), 5.

Russo, D. (2006). Effects of land abandonment on animal species in Europe: Conservation and management implications Integrated assessment of vulnerable ecosystems under global change in the EU. Project report. 52 pp. Università Degli Studi de Napoli Federico, Napoli, Italy.

Schils, R., Kuikman, P., Liski, J., Van Oijen, M., Smith, P., Webb, J., \& Hiederer, R. (2008). Review of existing information on the interrelations between soil and climate change.(ClimSoil). Final report (Technical Report). http://nora.nerc.ac.uk/id/eprint/6452.

Tallis, H., Kareiva, P., Marvier, M., \& Chang, A. (2008). An ecosystem services framework to support both practical conservation and economic development. Proceedings of the National Academy of Sciences, 105(28), 9457-9464.

TEEB (2010), The Economics of Ecosystems and Biodiversity Ecological and Economic Foundations. Edited by Pushpam Kumar. Earthscan, London and Washington

Ten Brink P., Badura T., Bassi S., Daly, E., Dickie, I., Ding H., Gantioler S., Gerdes, H., Kettunen M., Lago, M., Lang, S., Markandya A., Nunes P.A.L.D., Pieterse, M., Rayment M., Tinch R., (2011). Estimating the Overall Economic Value of the Benefits provided by the Natura 2000 Network. Final Report to the European Commission, DG Environment on Contract ENV.B.2/ SER/2008/0038. Institute for European Environmental Policy / GHK / Ecologic, Brussels 2011

Van Berkel, D. B., \& Verburg, P. H. (2014). Spatial quantification and valuation of cultural ecosystem services in an agricultural landscape. Ecological Indicators, 37, 163-174.

Väre, H., Lampinen, R., Humphries, C., \& Williams, P. (2003). Taxonomic diversity of vascular plants in the European alpine areas. In L. Nagy, G. Grabherr, C. Körner \& D. A. Thompson (Eds.), Alpine biodiversity in Europe (pp. 133-148). Berlin: Springer.

Verburg, P. H., \& Overmars, K. P. (2009). Combining top-down and bottom-up dynamics in land use modeling: Exploring the future of abandoned farmlands in Europe with the Dyna-CLUE model. Landscape Ecology, 24(9), 1167-1181. doi:10.1007/s10980-009-9355-7.

Viviroli, D., Dürr, H. H., Messerli, B., Meybeck, M., \& Weingartner, R. (2007). Mountains of the world, water towers for humanity: Typology, mapping, and global significance. Water Resources Research, 43(7), W07447.

Wild Europe. (2012). A working definition of European Wilderness and wild areas. Wild Europe Initiative.

WWF. (2010). Assessment of the restoration of potential along the Danube and main tributaries. Vienna: WWF. 